\title{
DENDROCHRONOLOGICAL STUDY OF Brosimum utile (Kunth) Oken FROM TIMBIQUÍ, CAUCA, COLOMBIA
}

\author{
Claudia Milena Parada-Rico ${ }^{1 *}$, César Augusto Polanco-Tapia ${ }^{2}$, Mario Tomazello-Filho ${ }^{3}$ \\ ${ }^{1 *}$ Universidad Distrital Francisco José de Caldas, Facultad del Medio Ambiente y Recursos Naturales, Bogotá D.C., Colombia, - \\ cmparada.r@gmail.com; cmparadar@correo.udistrital.edu.co \\ ${ }^{2}$ Universidad Distrital Francisco José de Caldas, Facultad del Medio Ambiente y Recursos Naturales, Bogotá D.C., Colombia - \\ cpolanco@udistrital.edu.co \\ ${ }^{3}$ Universidade de São Paulo - Escola Superior de Agricultura "Luiz de Queiroz", Departamento de Ciências Florestais, Piracicaba, São \\ Paulo, Brazil - mtomazel@usp.br
}

Received for publication: 01/06/2020 - Accepted for publication: 20/05/2021

\begin{abstract}
Resumo
Estudio dendrocronológico de Brosimum utile (Kunth) Oken procedente de Timbiquí, Cauca, Colômbia. Brosimum utile (Kunth) Oken é uma espécie com alto potencial madeireiro e altas taxas de colheita e mobilização na Colômbia. Com o objetivo de contribuir com elementos de manejo silvicultural para a floresta natural a partir de técnicas dendrocronológicas, que tendem ao uso sustentável da espécie, dez discos de madeira foram amostrados em toras basais, cuja origem foi Timbiquí, Cauca. As amostras foram preparadas na superfície, os anéis de crescimento foram visualizados e marcados. Com o auxílio da cofechado e análise dos valores da densitometria de raios X, realizada na ESALQ-USP, Brasil, as cronologias foram construídas, obtendo-se uma correlação de 0,692. Posteriormente, a cronologia padrão foi correlacionada com a intensidade de precipitação em uma série de 44 anos. O crescimento foi modelado pela equação de Von Bertalanffy e calculou-se o incremento corrente anual - ICA e o aumento médio anual - IMA, avaliados em cinco categorias de idade, obtendo-se média de 6,336 e 5,683 mm.ano ${ }^{-1}$, respectivamente.

Palavras-chave: anéis de crescimento, datação cruzada, incremento corrente anual - ICA, aumento médio anual - IMA, manejo florestal sustentável
\end{abstract}

Abstract
Brosimum utile (Kunth) Oken is a timber-yielding high-potential species with elevated rates of forest harvest
at large-scale commercial transport in Colombia. In order to provide silvicultural management elements for
natural forests, this study applied dendrochronological technique in a manner that promoted sustainable
methods to manage the species. In this study, ten timber dicks using wood-sampling logs from Timbiquí-Cauca
were used. The logs' surfaces were observed and prepared, and their growth rings were marked. By developing
cross-dating and x-ray densitometry value analysis, accomplished in ESALQ-USP, Brazil, the study established
the chronologies; and as a direct consequence, it obtained a correlation of 0.692 . Afterwards, the standard
chronology was correlated with rainfalls in a 44 -year series. The growth was modeled using the Von Bertalanffy
equation, and the current annual increment (CAI) and mean annual increment (MAI) were calculated, whose
results were classified into five age-categories, obtaining 6.336 and 5.683 mm.year ${ }^{-1}$ as final values,
respectively.
Keywords: Growth rings, cross-dating, current annual increment CAI, mean annual increment MAI, harvesting.

\section{INTRODUCTION}

The intense harvest of resources derived from tropical forests has given rise to a discussion on the implementation of sustainable management systems around the world, whose success is significantly dependent on the knowledge of trees' growth rates, in addition to the dynamics and productivity of forest mass as a whole (Worbes et al., 2003; Groenendijk, et al.,2017).

A very common problem in the forest sector is the lack of information in periodic records to estimate future variables (Polanco, 2004), where obtaining real growth data, necessary to determine felling volumes and cycles, poses a challenge for the sustainable management of natural forests (Sejana et al., 2016; Giraldo \& Del Valle, 2011). Obtaining information through permanent plots brings with it certain challenges, such as the cost of their installation and maintenance and the generation of short-term information. (Condit 1995; Clark \& Clark, 1992, 2001; as cited in Brienen, \& Zuidema ,2006). An alternative method to obtain these growth data is ring analysis, which offers advantages over the data obtained from permanent plots, such as age estimates calculated directly instead of based on simulations, obtaining growth rates obtained from representative trees that have satisfactorily reached the canopy, and obtaining growth patterns for the entire lifetime of a tree (Brienen \& Zuidema, 2006; Groenendijk, et al.,2017).

As of 2011, Colombia had a forest cover of approximately fifty-nine million hectares, then constituting a little over fifty-two percent of the continental surface of the national territory. From this surface, during the period between 2000 and 2011, seventeen million $\mathrm{m}^{3}$ of wood harvested were recorded. From this amount, approximately $46 \%$ originated in the states under the jurisdiction of the regional autonomous corporations - the governmental 
bodies who control environmental affairs locally — of Cauca, Nariño y Chocó, located in the country's Pacific Coast. (Olarte et al, 2013). One of the species harvested and transported from this area is Brosimum utile Kunth (Oken), which spreads from Mexico to the Amazon basin in Bolivia, at heights of up to 1400 meters above sea level. It is found in secondary forests, on fertile soils in solid ground (López, et al, 2014). The timber from this species is used to make plywood, tool handles, fishing rods, furniture, drawers, moldings, cladding, interior constructions and toys (López, et al, 2014; ITTO, 2018).

The assessment of climate factors would explain the cambium's response, with rainfall being a variable that incites its activity in the American tropic (Callado, et al., 2013; Carvalho et al., 2018; Schweingruber, 1988). Various tropical trees show yearly rings as a result of seasonal climate, and this could be used to determine the age of trees and their growth rate (Groenendijk, et al.,2017). In the year 1998 Vladimir Castelblanco tried to perform a dendrochronological analysis of $B$. utile without success, classifying it as non-susceptible to this type of studies.

Consequently, the main goal of this research is to perform a dendrochronological study in Brosimum utile from Timbiquí, Cauca, in the Colombian Pacific Coast, based on the analysis of growth rings found in the species, identifying the features of the log's anatomy associated with ring visibility, recognizing the pattern of periodicity in the formation of growth rings, identifying the environmental signals that stimulate cambium, and modeling the species's growth, in order to define sustainable management practices.

\section{MATERIALS AND METHODS}

\section{Study area}

Samples were obtained as logs from wood collection centers in the District of Buenaventura, next to the neighborhood Antonio Nariño, whose origin, according to the owner of the transformation center, is in the township of Puerto Saija, Timbiquí, Cauca (A). The municipality of Timbiquí recognizes that it is necessary to encourage the forest sector and through policy tools and projects to promote the establishment of industrial forest exploitation points in a sustainable manner (Alcaldía Municipal de Timbiquí, 2016).

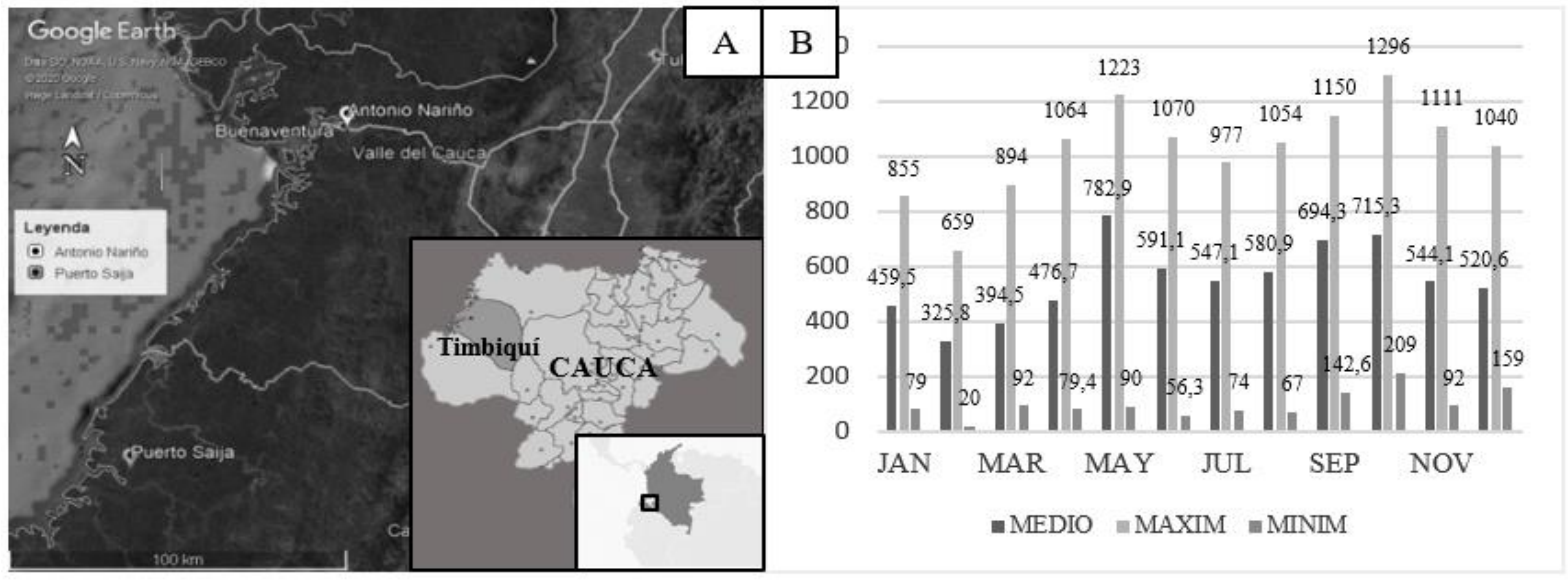

Figure 1. A. Wood origin: Puerto Saija, Cauca. Geographical source of wood samples for testing: Buenaventura, Valle del Cauca. B. Rainfall rates (mm.year ${ }^{-1}$ ), along with minimum, mean and maximum values for the 1966-2010 research period in Puerto Saija, Cauca.

Figura 1. A. Origem da madeira: Puerto Saija, Cauca. Ponto de coleta das amostras: Buenaventura, Valle del Cauca. B. Regime de chuvas (mm.ano-1 ${ }^{-1}$, com valores médios, máximos e mínimos para o período 19662010 na cidade de Puerto Saija.

The municipality of Timbiquí show an average annual rainfall of $5500 \mathrm{~mm}$ and an average temperature of $27^{\circ} \mathrm{C}$, according to the data obtained by the Saija rainfall station, obtained by the Institute of Hydrology, Meteorology and Environmental Studies IDEAM; rainfall can reach up to $6400 \mathrm{~mm}$ per year, under a bimodal behavior, with periods of greater rainfall between April-June and September-October (Figure 1B).

\section{Species selection, sample collection and preparation}

The species $B$. utile was selected in this study because of its importance in the national market for natural forest wood, as well as its high use in the industrial context. The study also considered the frequency, speed and form of growth that make the species a benchmark for forest management plans in the areas where it grows. 
The sampling was done at random at a log collection center for transformation, where, based on the experience of the communities and stakeholders involved in local harvesting, the basal logs and their direction in the axial axis of the tree were identified, ensuring that the samples were located in the $0.5-1 \mathrm{~m}$ section, with a thickness of 0.04-0.06 m. According to the records of the company that donated the materials, the harvest occurred in December 2017. The samples were obtained with a chainsaw in February 2018; they were identified, marked, measured and packed for transport in the same month, sent to the wood technology laboratory of Universidad Distrital in the city of Bogotá, where they remained for four months to allow natural drying. During this period, Sodium Chloride $(\mathrm{NaCl})$ was used to avoid the presence and growth of fungi and to stimulate dehydration. Subsequently, in June 2018, the preparation of the material began through manual sanding using emery cloth sheets number 80, 120, and 180 and then sandpaper sheets number 280, 400 and 600, as recommended by Schweingruber, 1988.

\section{Macroscopic observation and manual marking of rings}

Following the methodology suggested by Schweingruber (1988), observations were made with a 10X magnifying glass, recognizing the anatomical features associated with growth ring visibility. The type of ring was identified; it was demarcated by fibrous zones classified as latewood. The growth rings of one to two radii per section were manually marked for subsequent measurement of their width (

Figure 2).

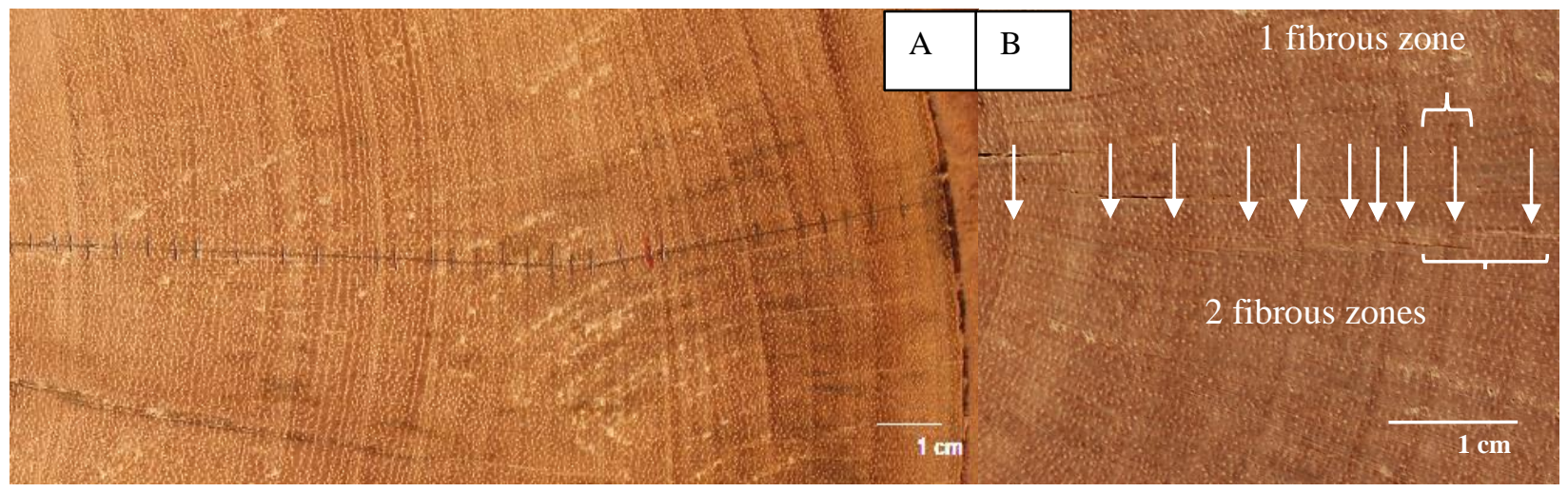

Figure 2. A. Growth rings marked manually B. Definition and marking of fibrous zones.

Figura 2. A. Marcação manual dos anéis de crescimento. B. Demarcação e definição das áreas fibrosas.

Considering the density of the wood from B. utile, it was presumed that its annual growth could be demarcated not by one, but by two fibrous zones, which is why the study included a correlation analysis to identify how many fibrous zones are created in a period of one year (

Figure 2B).

\section{Analysis with X-ray densitometry}

Densitometry tests were performed in the dendrochronology laboratory of Universidad de São Paulo, Brazil. To obtain the material for analysis, the samples were cut transversely to obtain 2 mm-thick sheets; these sheets were taken to a controlled temperature and humidity chamber with $20{ }^{\circ} \mathrm{C}$ and $50 \%$ humidity for approximately 12 hours, to achieve a moisture content of $12 \%$. Later, the slides were scanned in the radial plane with X-rays. To do this, the QTRS-01X equipment was used and the data were analyzed with the QMS software (Leite, et al., 2016; Pagotto et al., 2017). Graphs were constructed from these tests, with the values of the apparent density of the wood (Leite et al., 2016).

\section{Capture of images and measurement of ring widths}

Acknowledging the use and application of digital images to analyze the anatomy of the wood, as they allow improving precision and speed when measuring of xylem elements (Alvarado et al., 2010), photographs of 
each slice were taken, for the subsequent measurement of the rings marked using the scientific image analysis and processing software Image proß plus.

\section{Crossdating and construction of the chronology}

To have control over the measurements, to evaluate the quality of the crossdating, i.e., the correlation between trees, and to guarantee the accuracy of the measurements, this study used the COFECHA program, ensuring that the environmental signal was maximized (Herrera \& Del Valle, 2011). To do the crossdating, a total of 10 data series were used for nine individuals, having marked two radii for the Bu4 sample and a single radius for the remaining samples. Time windows of 10 and 15 years were also used according to the length of the series.

Afterwards, the chronology was constructed, eliminating growth trends and serial autocorrelation, standardizing the series and calculating the Arstan and Residual chronologies (Herrera \& Del Valle, 2011) . Ring indexes in ARSTAN were obtained, and a spline adjustment of 50\% was applied. Presuming one or two growth periods in the same year, correlations were experienced in COFECHA with one and two fibrous zones.

\section{Identification of climate signals and determination of the periodicity in ring formation}

To identify climate signals in the cambial activity, this study used a Pearson correlation between the width of the rings and the rainfall values reported by the IDEAM rainfall station: 53060020, located in the town of Puerto Saija next to the bank of the Saija river, see (Figure 1B); therefore, the relationship of these variables was in a period of 44 years, between 1966 and 2010. The periodicity in the formation of the rings was determined by identifying the number of fibrous zones formed in one year, through correlations in COFECHA both for growth rings marked by a fibrous zone, and for two fibrous zones in an annual period.

\section{Diameter increase calculation according to the Von Bertalanffy growth model}

The calculation of the diameter throughout time $(\mathrm{t})$ was done using the Von Bertalanffy growth equation:

$$
D=A\left(1-b e^{-k t}\right)^{\frac{1}{(1-m)}}
$$

Where: $\mathrm{D}=\mathrm{DBH}, \mathrm{A}=$ Asymptote $(150 \mathrm{~cm}), \mathrm{k}, \mathrm{b}, \mathrm{m}=$ Equation parameters, $\mathrm{t}=$ Age in years and $\mathrm{e}=$ Euler's constant. (Bertalanffy, 1976; Giraldo \& Del Valle, 2011b)

The asymptote $(150 \mathrm{~cm})$ was obtained by checking secondary information, according to the indications of ITTO, 2018.

\section{Determination of equation parameters}

To determine the parameters in the application of the model, the study used the graphing calculator DESMOS $®$, which allowed simultaneous variations in all parameters at convenient intervals which were determined beforehand by the authors. In this way, the most suitable combination that maximized the correlation coefficients was selected.

\section{Calculation of CAI and MAI values}

The current annual increment (CAI) and mean annual increment (MAI) were calculated according to the following equations:

$$
\begin{gathered}
I C A=D^{\prime}=A * k *\left(\frac{1}{1-m}\right)\left(1-e^{-k t}\right)^{\left(\frac{1}{1-m}\right)-1} e^{-k t} \\
I M A=\frac{D}{t}=\frac{A\left(1-b e^{-k t}\right)^{\left(\frac{1}{1-m}\right)}}{t}
\end{gathered}
$$

Where: $\mathrm{D}=\mathrm{DBH}, \mathrm{A}=$ Asymptote, $\mathrm{k}, \mathrm{b}, \mathrm{m}=$ Equation parameters, $\mathrm{t}=$ Age in years and $\mathrm{e}=$ Euler's constant (Giraldo \& Del Valle, 2011)

\section{RESULTS}

\section{Crossdating and construction of the chronology}

After assessing the growth ring demarcation by direct observation, the analysis of densitometry data suggested that said demarcation does indeed respond to fibrous zones whose density is higher in the observed plane of the wood, and it is classified as latewood with darker colorations. This analysis by densitometry 
complemented the observation analysis and made it more conclusive; the observation analysis by itself it made demarcation difficult.

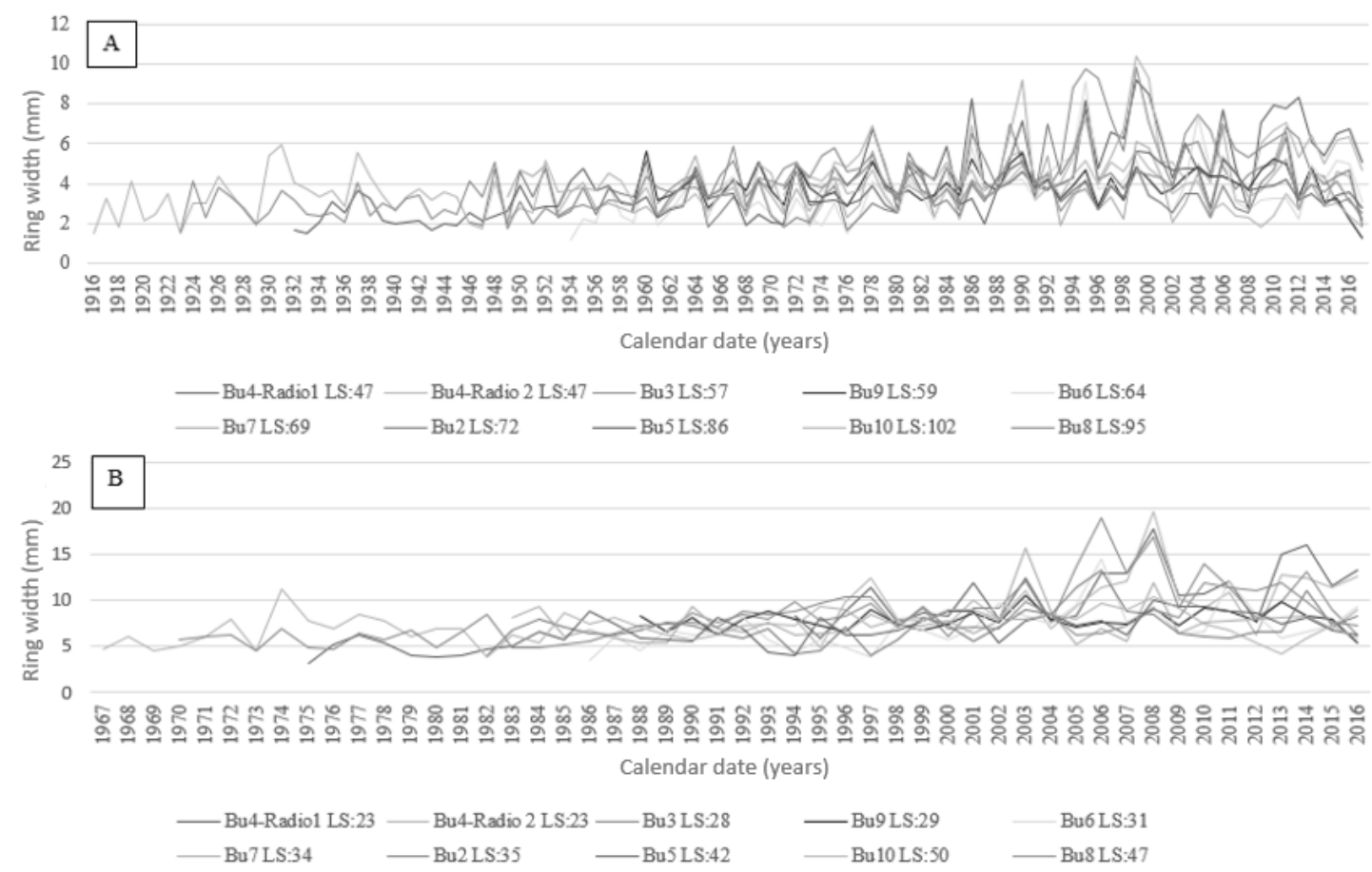

LS: It represents the length of the series in years. LS:47 indicates a series of 47 years

Figure 3. A. Ring width from 10 radii for nine different individuals, assuming only one annual fibrous zone. B. Ring width from 10 radii for nine different individuals, assuming two fibrous zones formed in the same year.

Figura 3. A. Largura do anel de 10 raios para nove indivíduos diferentes, assumindo uma única zona fibrosa anual. B. Largura do anel de 10 raios para nove indivíduos diferentes, assumindo duas zonas fibrosas formadas no mesmo ano.

After identifying and measuring the width of growth rings (Table 1), and recognizing the correlations of the series shown in (Table 1), the formation of a single fibrous zone in one year, whose correlation values were above 0.6 , is considered more accurate.

Table 1. Correlation values between series obtained by cross-dating for one and two fibrous zones.

Tabela 1. Valores de correlação entre as séries obtidas por cofechdo para uma e duas zonas fibrosas.

\begin{tabular}{cccc}
\hline Assessed samples & Length of time window & \multicolumn{2}{c}{ Correlation in COFECHA } \\
\hline Sample & Years & $\mathbf{1 Z F}$ & $\mathbf{2 Z F}$ \\
\hline ALL & 15 & 0.692 & 0.208 \\
\hline Bu2- Bu3- Bu5- Bu6- & 15 & 0.682 & 0.15 \\
Bu7- Bu8- Bu9- Bu10 & & & 0.135 \\
\hline Bu5- Bu8- Bu10 & 10 & 0.653 & -0.133
\end{tabular}

1ZF: One fibrous zone per calendar period of one year. 2ZF: Two fibrous zones per calendar period of one year

\section{Identification of climate signals and determination of the periodicity of ring formation}

According to the correlations in (Table 1) the periodicity of ring formation was recognized with the demarcation of a single growth ring in a calendar year, ruling out two annual fibrous zones.

The correlation between the series of ring width and the medium and minimum monthly rainfall values for the 1966-2010 period allowed associating ring formation with decreases in rainfall, (FEBa) and, on the other hand, it showed a lower growth with the months of medium to high rainfall ( $\mathrm{SEPb}$ and JULp). 


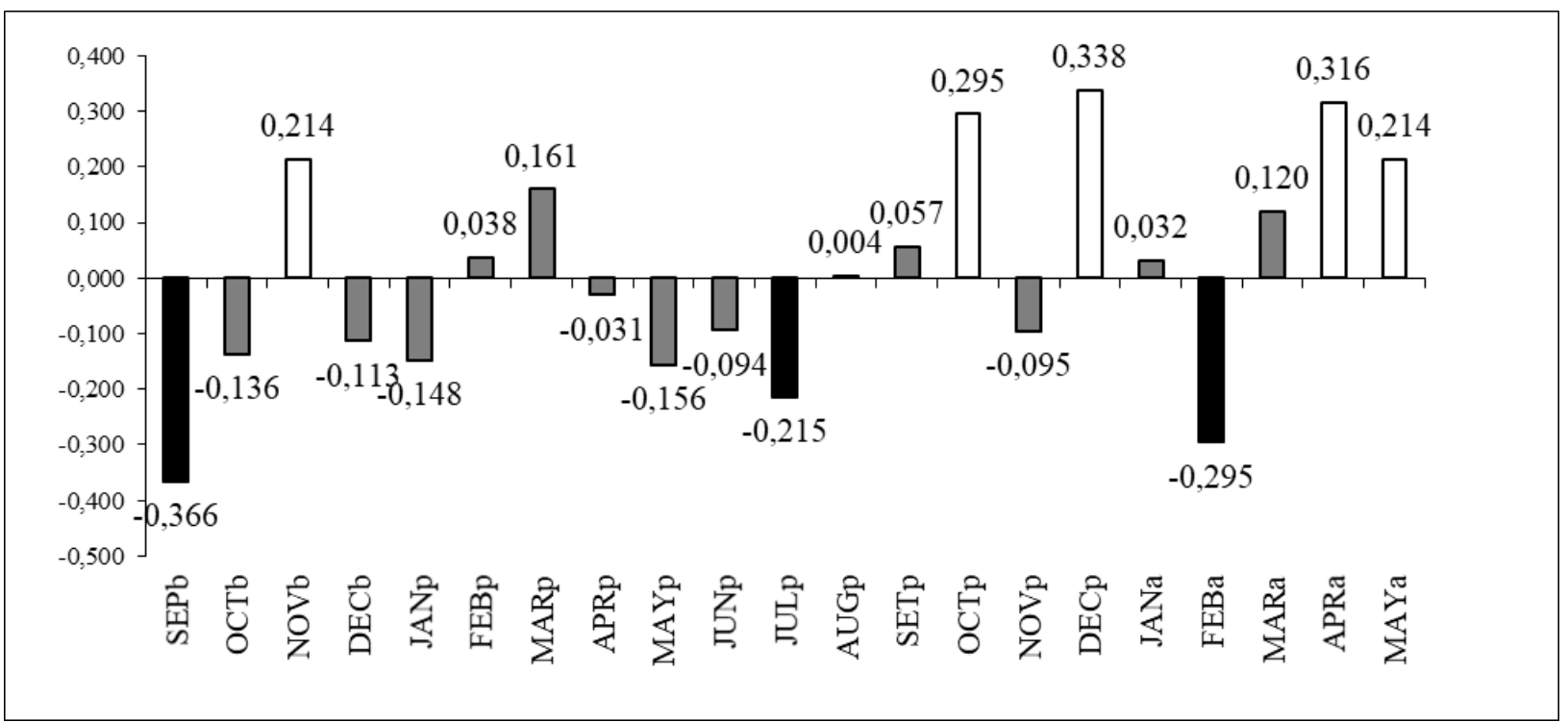

Figure 4. Correlation between rainfall (1966-2010) and the residual chronology for the evaluated series with one fibrous zone per year. Showing months of the year before (b), the present year (p) and the year after (a). Figura 4. Correlação entre precipitação (1966-2010) e cronologia residual para as séries avaliadas com uma zona fibrosa por ano. Mostrando os meses do ano anterior (b), o ano atual (p) e o ano após (a).

Greater cambial activity is identified in the months of October, November and May, which coincide with the times of greatest rainfall, without reaching extreme values ( $\mathrm{SEPb}$ ), which would be inducing cambial activity. Likewise, less cambial activity is recognized in months like July and February (JULp and FEBa); the latter two coincide with the times of lower medium rainfall and lower average minimum rainfall (Figure 1B).

Taking into account that a single fibrous zone is formed during the calendar year, the correlation values between rainfall and growth show contrasting values. The foregoing suggests that the species $B$. utile has limits in growth conditioned by rainfall; these limits produce the best expression in the growth ring width; thus, months with precipitation peaks generate responses similar to months with valleys in this variable (Figure 4).

\section{Diameter increase calculation using the Von Bertalanffy model}

The growth speed among the sampled individuals was different. This is associated with environmental variables or conditions, either natural or anthropic, because the area is an important object of silvicultural and harvesting activities, which may represent better conditions for growth. Thus, the individuals that exhibited the highest growth rates were $\mathrm{Bu} 3$ and $\mathrm{Bu} 4$ (Figure 5A).

The average increase in diameter, calculated using the model used, sheds light on the growth rate of the species, which, as in the individual cases analyzed, is faster in the initial stages and acts the opposite way in the final stages, (Figure 5B).

\section{Calculation of CAI and MAI values}

The calculation of CAI and MAI indicates a rapid initial growth, with greater activity of the cambium in the juvenile and mature stages, where the curves show the greatest slopes, until it reaches a point of inflection or transition where growth stabilizes. This is clearly visible when identifying the maximum value of the CAI, defined at an approximate average age of 38 years. Once CAI decreases, the intersection point of the curves takes place. It show the best time for harvest from a silvicultural point of view (Barrero., et al, 2011); therefore, the average age in the intersection point between CAI and MAI is 72 years (Figure 5B). 

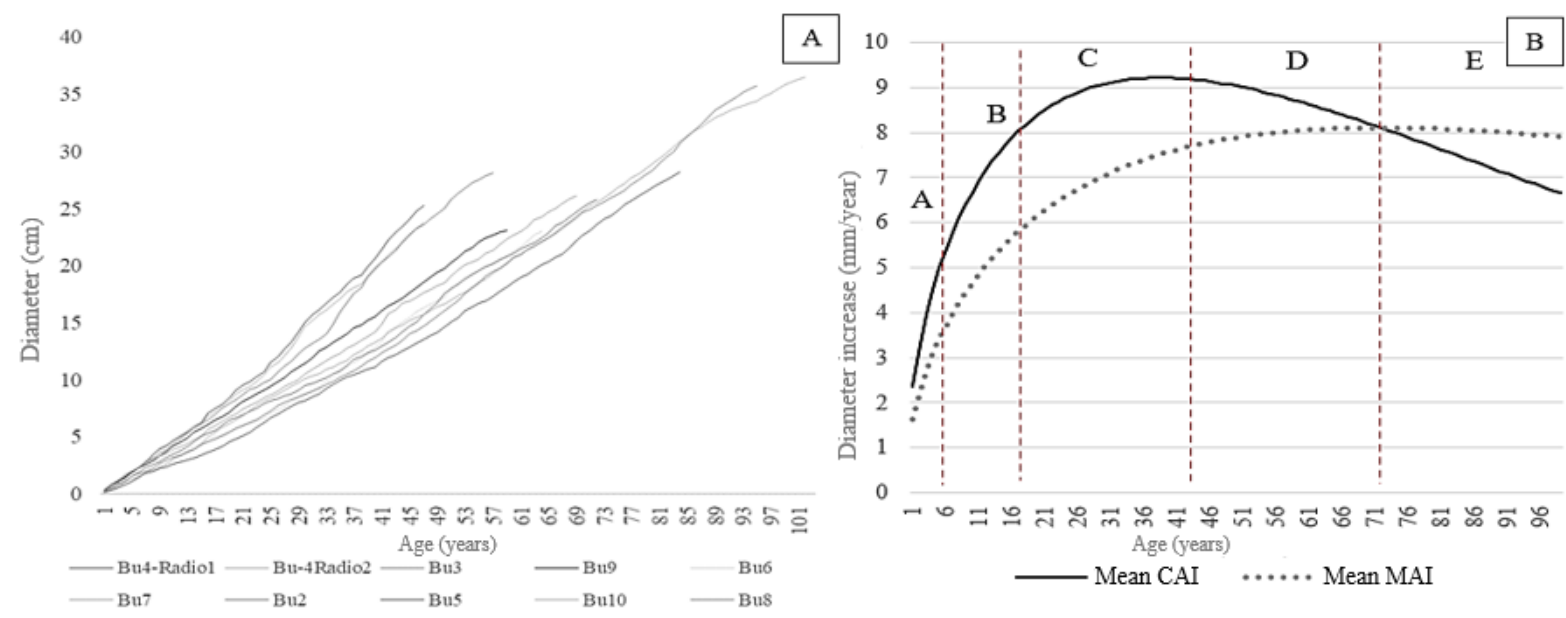

Figure 5. A. Cumulative growth curves for each sample, according to Von Bertalanffy's equations. B. Median curves of CAI and MAI and delimitation of age categories for all samples.

Figura 5. A. Curvas de crescimento cumulativo para cada uma das amostras usadas neste estudo de acordo com as equações de Von Bertalanffy. B. Curvas médias ICA e IMA e delimitação das categorias de idade, usando todas as amostras.

\section{Determination of growth rates by age categories}

Age categories A, B, C, D and E were identified throughout the life of the sampled individuals, in periods ranging from 0-5 years, 6-15 years, 16-38 years, 39-72 years and over 72 years, respectively, (Figure $5 \mathrm{~B})$.

Figure 5 Category A was defined as the initial growth, characterized in the CAI and MAI curves as the steepest, until the beginning of $\mathrm{B}$, where a change in the slope is visible. The category is delimited at the beginning of $\mathrm{C}$, with a transition of growth stabilization that continues up to the maximum CAI point, marking the beginning of $\mathrm{D}$, which is delimited in the cut point between the curves. In category $\mathrm{E}$, a notable reduction in the increments is identified; it was calculated until the year 300 where the diameter is already asymptotic. To verify the existence of significant differences between the defined age categories, an ANOVA was performed (

Table 2).

Table 2. Mean ANOVA values of CAI and MAI, among age categories.

Tabela 2. ANOVA dos valores médios de ICA e IMA entre as categorias de idade.

\begin{tabular}{cllll}
\hline Age category & \multicolumn{2}{l}{ Mean CAI values $(\mathbf{m m})$} & \multicolumn{2}{l}{ Mean MAI values $(\mathbf{m m})$} \\
\hline & F & Critical F & F & Critical F \\
\hline A-B & 18.315 & 4.494 & 13.866 & 4.494 \\
\hline B-C & 6.175 & 4.494 & 9.370 & 4.494 \\
\hline C-D & 0.001 & 4.494 & 2.618 & 4.494 \\
\hline D-E & 106.314 & 4.494 & 6.858 & 4.494 \\
\hline
\end{tabular}

The variance analysis (

Table 2) indicates significant differences between categories A-B, B-C, and D-E. Due to the symmetric behavior of the data during the period that comprises the C-D range delimited by the maximum CAI value, no statistically significant differences were found. However, the data for this period from year 16 to year 72 are found to be in two different categories due to the rising trend in the increase between years 16 to 38 , and the declining trend in the increase between years 39 to 72 . 
Table 3. Current and mean annual increment in mm.year ${ }^{-1}$ per each agecategory.

Tabela 3. Aumento anual atual e médio em mm.ano ${ }^{-1}$ por categoria de idade.

\begin{tabular}{ccccccccccc}
\hline \multicolumn{7}{c}{ CAI and MAI (mm.year ${ }^{-1}$ PER AGE CATEGORY } \\
\hline Sample & A (0-5 years) & B (6-15 years) & C (16-38 years) & D (39-72 years) & \multicolumn{2}{l}{ D (73-300 } \\
& CAI & MAI & CAI & MAI & CAI & MAI & CAI & MAI & CAI & MAI \\
\hline Bu2 & 4.176 & 3.050 & 6.424 & 4.851 & 7.807 & 6.355 & 7.728 & 7.174 & 3.638 & 5.972 \\
\hline Bu3 & 4.921 & 3.224 & 8.920 & 6.159 & 11.355 & 8.831 & 10.511 & 10.094 & 3.229 & 7.293 \\
\hline Bu4 & 3.959 & 2.285 & 9.007 & 5.546 & 12.818 & 9.156 & 11.930 & 11.088 & 2.985 & 7.736 \\
\hline Bu5 & 2.576 & 1.674 & 4.888 & 3.287 & 6.874 & 4.993 & 7.505 & 6.236 & 3.835 & 5.757 \\
\hline Bu6 & 3.070 & 1.999 & 5.764 & 3.900 & 7.922 & 5.845 & 8.325 & 7.149 & 3.747 & 6.195 \\
\hline Bu7 & 5.679 & 4.602 & 7.387 & 6.172 & 8.061 & 7.212 & 7.493 & 7.563 & 3.496 & 5.941 \\
\hline Bu8 & 1.963 & 1.122 & 4.736 & 2.824 & 7.656 & 5.037 & 8.764 & 6.839 & 3.880 & 6.313 \\
\hline Bu9 & 4.964 & 3.633 & 7.556 & 5.743 & 8.971 & 7.426 & 8.538 & 8.214 & 3.527 & 6.430 \\
\hline Bu10 & 3.024 & 1.969 & 5.683 & 3.843 & 7.827 & 5.767 & 8.254 & 7.067 & 3.757 & 6.157 \\
\hline Average & 3.815 & 2.617 & 6.707 & 4.703 & 8.810 & 6.736 & 8.783 & 7.936 & 3.566 & 6.422 \\
\hline
\end{tabular}

The growth calculated in the different age categories of the tree allows identifying that during the first five (5) years the increase is lower with approximately 3.815 mm.year ${ }^{-1}$ of CAI and 2.617 mm.year $^{-1}$ of MAI, while the D age category has CAI values that reach 8.783 mm.year ${ }^{-1}$, and 7.936 mm.year $^{-1}$ for MAI (Table 3).

\section{DISCUSSION}

During this research, it was possible to delimit and correlate the rings to model the growth of the species in the sampling area, despite the fact that Castelblanco, 1998 had performed the dendrochronological assessment of this species and had ruled out continuing the analysis with cross-dating and climate correlation due to the degree of difficulty delimiting the rings. Cross-dating allowed identifying a correlation of 0.69 after identifying the delimitation of rings formed by a single fibrous zone during a period of an almost yearly recurrence.

Growth rates are identified for Guandal and Catival species according to the reports of Castelblanco, 1998 and Giraldo \& Del Valle, 2011. The former determines growth rates of $0.863 \mathrm{~cm} /$ year, $1.303 \mathrm{~cm} /$ year, 0.66 $\mathrm{cm} /$ year and $1.579 \mathrm{~cm} /$ year for Carapa guianensis, Otoba latialata, Symphonia globulifera y Virola sebifera respectively. As for the mean growth rate found by Giraldo \& Del Valle, 2011 for Prioria copaifera from the alluvial plane of the Atrato river, it is considerably lower than the one found for $B$. utile, with a difference of 2.583 mm.year ${ }^{-1}$. According to Del Valle 1994, as cited in Castelblanco, 1998, this difference may be due to the fact that the growth rate in swamp forests is not determined by the fertility of the soils that develop on the peat, but by the intensity of use of the forest, which reduces the basal area and the competition for nutrients and light, increasing the growth rate. Likewise, Lisi et al., 2008 state that for 24 species from southeastern Brazil, the dynamics of diameter increase respond to changes in rainfall, with greater increases in the rainy seasons.

Traditionally, the idea that a Minimum Cutting Diameter (MCD) of $40 \mathrm{~cm}$ is adequate for the application of selection felling methods or other silvicultural practices acceptable for management has been widespread in Colombia, and it has even been promoted by national regulations — among others, by Decree 1383 of 1940 (Linares, 2015), but his diameter does not apply to B. utile. The MCD found for B. utile was $58 \mathrm{~cm}$, determined by identifying the intersection point of the CAI and MAI curves, according to the growth rate of the species. This diameter not only exceeds the one established by law, but also the diameter of $43 \mathrm{~cm}$ used by industrialists to guarantee the optimum commercial value in the manufacture of plywood, without taking into account aspects of sustainable management. In relation to the above and considering the growth rates found in this research and the MCD used by the industrialists in Antonio Nariño, Buenaventura, for $B$. utile, it can be inferred that the trees of this species are still used in their juvenile stages, which can generate an imbalance in the structure and composition 
of the forest, causing its degradation (Linares, 2015). This can also have an impact on the presence of cracks or imperfections in the wood, as it has lower strength and stiffness in compression to allow the reorientation of the fibers more easily due to growth stress (Meinzer, et al., 2011), affecting its potential use.

In Colombia, the traditional processes of forest use have been limited to very few woody species, where the processing of wood with a chainsaw does not focus on added value (Polanco., et al, 2014). Therefore, the use of mature trees could increase said added value with better strength characteristics in the wood and better performance in its use, as each age category is associated with its own physiological and mechanical characteristics, in relation to the tree's requirements (Meinzer, et al., 2011). During the juvenile stages defined in categories A, B and C, the cambium cells are derived from apical meristems. In these early years, especially in categories $\mathrm{A}$ and $\mathrm{B}$, the tree must withstand negative pressure to avoid mechanical failure, and small diameters must have high tensile strength to avoid breaking, so they have low stiffness. Meanwhile, in mature stages such as $\mathrm{D}$ and $\mathrm{E}$, the initial cambial divisions have the ability to mature gradually according to the needs of the tree, and they have greater transport capacity that compensates for the increase in strength and stiffness as it has to withstand greater compression loads due to the weight of the tree itself (Meinzer, et al., 2011). Additionally, as noted by Martínez et al., 2017 as a criterion to select trees for felling, in order to obtain logs, woods and boards, trees of diameters larger than $40 \mathrm{~cm}$ are harvested.

\section{CONCLUSIONS}

- The application of dendrochronological techniques in B. utile - a common species in tropical forests - is possible for dating, for correlation with climate variables and for modeling the growth of individuals, considering the correlation of 0.69 obtained through cross dating.

- The growth rings of B. utile are delimited by fibrous zones, which form stripes of latewood that are recognized by their darker coloration and because they show greater density, a characteristic that must be evaluated by densitometry tests in conjunction with observation to improve demarcation.

- The periodicity pattern in the formation of the growth rings was determined as very close to a yearly recurrence, with the formation of a single fibrous zone in one year. With the formation of a single fibrous zone in a year, the study identified that the highest growth in diameter occurs during the months of October and May, which show some of the highest average rainfall levels. The analysis of growth rings in this species allowed identifying environmental signals that incite cambial activity, where a relationship was detected between the formation of rings with decreases in rainfall; thusly, the periods with increases in rainfall up to a certain limit were related to higher cambium activity.

- According to the intersection point between the CAI and MAI curves, there is an optimal harvest diameter of $58 \mathrm{~cm}$ for the species, which would be reached in the year 72. The average calculated CAI was $6.336 \mathrm{~mm}^{-y e a r^{-1}}$ and the average calculated MAI was 5.683 mm.year ${ }^{-1}$. These growth rates, the MCD suggested by Colombian legislation and the DMC demanded by the industry for the manufacture of plywood -40 and $43 \mathrm{~cm}$, respectively — indicate that a considerable amount of the harvested individuals is made up of trees that are still in juvenile states, whose wood has less strength and stiffness in compression, reducing its grade and increasing its susceptibility to biological attack with the consequential reduction in potential uses.

\section{ACKNOWLEDGEMENTS}

We would like to acknowledge Universidad Distrital Francisco José de Caldas in Bogotá D.C. and Universidad de São Paulo, Luiz de Queiroz School of Agriculture, Brazil.

\section{REFERENCES}

ALCALDÍA MUNICIPAL DE TIMBIQUÍ. Plan De Desarrollo Municipal 2016-2019. Timbiquí, 2016.

ALVARADO, J. R.; CHAVES, P. P.; MOREANO, V.; VERA, A.; ORTEGA, D. R.; TAPIA, A. A.; LlACSAHUANGA, J.; CORONADO, P.; ZÚÑIGA, C.; LOZANO, C.; LOBÃO, M. S.; CHAVESTA M. Aplicación de la técnica de análisis de imagen digital para caracterización y medición de elementos xilemáticos de especies forestales, Xilema, Lima, v.23, p. 62 - 69, 2010.

BARRERO, H.; ÁlvareS, D.; NEPVEU, G.; GARCÍA, I.; GUERA, M. Turno de corta para Pinus caribaea Morlet Var. Caribaea Barret y Golfari en la empresa Forestal Integral "Macurije", Avances, Pinar del Río, v. 13, n. 2. 2011.

BertalanfFy, V. L. (1976). Teoría General De Los Sistemas, Fundamentos, Desarrollo, Aplicaciones. Mexico: Fondo de Cultura Económica, 1976, 311 p. 
BRIENEN, R. J. W.; ZUIDEMA, P. A. The use of tree rings in tropical forest management: projecting timber yields of four Bolivian tree species. Journal of Ecology, United Kingdom, v. 94, p. 481 - 493, 2006.

CALlado, C., ROIG, F., TOMAZELlO, M., \& BARROS, C. Cambial growth periodicity studies of South American woody species-a review. IAWA Journal, Leiden, v. 34, n. 3, p. 213 - 230, 2013.

CARVAlho, D. C.; PEREIRA, M. G.; FIGUEIREDO, J. V.; CAMARGO, J. H.; SILVEIRA, L. D.; FIGUEIREDO J. Dendrochronology and growth of Copaifera langsdorffii wood In the vegetative dynamics of the Pirapitinga ecological station, State of Minas Gerais, Brazil. Floresta, Curitiba, v.48, n. 1, p. 49 - 58, 2018.

CASTELBLANCO, V. Estudio dendrocronológico de nueve especies forestales del bosque de Guandal en el bajo Río San Juan- Buenaventura. Bogota D.C.: Universidad Distrital Francisco José De Caldas, 1998.

GIRALDO, J. A.; DEL VALLE, J. I. Estudio del crecimiento de Prioria copaifera (Caesalpinaceae) mediante técnicas dendrocronológicas. Biología Tropical, Medellín, v.59, n. 4, p. 1813 - 1831, 2011.

GROENENDIJK, P.; BONGERS, F.; ZUIDEMA, P. A. Using tree-ring data to improve timber-yield projections for African wet tropical forest tree species. Forest Ecology and Management, Wageningen, v. 400, p. 396 - 407, 2017.

HERRERA, D. A.; DEL VALLE, J. I. Reconstrucción de los niveles del Río Atrato con anillos de crecimiento de Prioria copaifera. Dyna, Medellín, v. 78, p. 121 - 130, 2011.

INTERNATIONAL TROPICAL TIMBER ORGANIZATION (ITTO). Lesser used species. Sande (Brosimum utile). Available in: http://www.tropicaltimber.info/es/specie/sande-brosimum-utile/ Access on: 23 May. 2018.

LEITE, P. T.; TOMAZELLO M.; CERDEIRA, L.P. Management of Cerrado Trees using growth rings. Australian journal of basic and applied sciences, São Paulo, v. 10, p. 92 - 103, 2016.

LINARES, R. Guía Para El Desarrollo de la Ordenación Forestal Integral y Sostenible En Colombia. Bogota D.C.: Ministerio de Medio Ambiente y Desarrollo Sostenible, 2015, 177 p.

LISI, C. S.; TOMAZELLO, M., BOTOSSO, P.C.; ROIG, F.A.; MARIA, V.R.; FERREIRA-FEDELE, L.; VOIGT, A. Tree-Ring formation, radial increment periodicity, and phenology of tree species from a seasonal semideciduous forest in southeast Brazil. IAWA Journal, Leiden, v. 29, n. 2, p. 189 - 207, 2008.

LÓPEZ, R.; PULIDO, E.; GONZÁLES, R.; NIETO, J.; VÁSQUEZ, M. (2014). Maderas. Especies comercializadas en el territorio CAR Guía para su identificación. Bogota D.C: Corporación Autónoma Regional de Cundinamarca CAR, 1 ed. 2014, 120 p.

MARTÍNEZ, M.; TORRES, J. J.; MEDINA, H. H. Aprovechamiento forestal maderable en cuatro municipios del departamento de Chocó, Colombia. Revista de Investigación Agraria y Ambiental, Bogotá D.C., v. 6, n. 2, p.57 $-73,2017$.

MEINZER, F. C.; LACHENBRUCH, B.; DOWSON, T. Size-and age-related changes in tree structure and function. Heidelberg: Springer Netherlands, 1 ed. 2011, 514 p.

OLARTE, C.; RIVERA, I.; PADILLA, L.; ÁLVEREZ, M.; LADINO, M.; CUÉLLAR, M. Boletín Forestal 2011. Bogota D.C.: Instituto de Hidrología, Meteorología y Estudios Ambientales IDEAM, 1 ed. 2013, 70 p.

PAGOTTO, M. A.; DESOTO, L.; CARVAlHO, A.; NABAIS, C.; TOMAZELlO, M.; RIVEIRO, A.; LISI, C. S. Evaluation of X-ray densitometry to identify tree-ring boundaries of two deciduous species from semi-arid forests in Brazil. Dendrochronologia, Sergipe, v. 42, p. 94 - 103, 2017.

POLANCO, C. A. Modelo determinístico-estocástico para el cálculo de variables sin registros históricos. Estudio de caso: Generación de residuos madereros en la localidad de Barrios Unidos, Bogotá D.C. Colombia. Colombia Forestal, Bogotá D.C., v. 9, p. 128 - 148, 2004.

SCHWEINGRUBER, F.H. Tree Rings: Basic and applications of dendrochronology. Dordrecht, Holland: Kluwer Academic Publishers Group, 2 ed.1988, 276 p.

SEJANA, A. R.; BARBOSA, A. C.; JUNK, W. J.; NUNES DA CUNHA, C.; PIEDADE, M.; SCABIN, A. B.; CECCANTINI, G. C.; SCHÖNGART, J. Growth models based on tree-ring data for the Neotropical tree species Calophyllum brasiliense across different Brazilian wetlands: implications for conservation and management. Trees, v. 31, p. $729-742,2016$.

WORBES, M.; STASCHEL, R.; ROLOFF, A.; JUNK, W. J. Tree ring analysis reveals age structure, dynamics and wood production of a natural forest stand in Cameroon. Forest Ecology and Management, v. 173, p. 105 $123,2003$. 